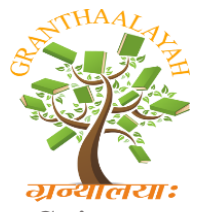

Science

INTERNATIONAL JOURNAL OF RESEARCH GRANTHAALAYAH A knowledge Repository

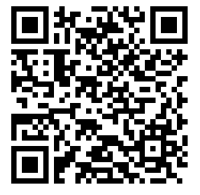

\title{
ROLE OF REMOTE SENSING AND GEOGRAPHIC INFORMATION SYSTEM TO ANALYZE THE IMPACT OF CLIMATE CHANGE ON FOREST ECOSYSTEMS
}

\author{
Mohommad Shahid*1, Shambhu Prasad Joshi ${ }^{2}$ \\ ${ }^{1,2}$ Ecology Research Laboratory, Department of Botany, \\ DAV (PG) College, Dehradun, Uttarakhand, INDIA
}

\begin{abstract}
Climate change is an inevitable process impacting the forest ecosystem. Various impacts like treeline shift, forest fires, and Species distribution are due to the effect of climate change. Green House Gases concentration in the atmosphere is increasing day by day due to anthropogenic activities. The pace of climate change is very alarming which will have the substantial impact on the forest ecosystem. Role of remote sensing and geographic information system in observing the forest ecosystem was reviewed. Spatio-temporal analysis of change in forest structure can be proficiently done with the help of remote sensing and geographic information system. Climate Change Mitigation programmes like Reducing Emissions from Deforestation and Forest Degradation (REDD-plus) can be implemented with the help of remote sensing and geographic information system. Baseline data generation using remote sensing and geographic information system can be useful in designing the policies for forest management and monitoring.
\end{abstract}

Keywords:

Climate change, forest ecosystem, Green House, Forest Degradation, geographic information system.

Cite This Article: Mohommad Shahid, and Shambhu Prasad Joshi, "ROLE OF REMOTE SENSING AND GEOGRAPHIC INFORMATION SYSTEM TO ANALYZE THE IMPACT OF CLIMATE CHANGE ON FOREST ECOSYSTEMS" International Journal of Research - Granthaalayah, Vol. 3, No. 8(2015): 61-68. DOI: 10.29121/granthaalayah.v3.i8.2015.2959.

\section{INTRODUCTION}

The latest analysis of observations from the World Meteorological Organization (WMO) Global Atmosphere Watch Programme shows that the globally averaged mole fractions of $\mathrm{CO}_{2}, \mathrm{CH}_{4}$ and $\mathrm{N}_{2} \mathrm{O}$ reached new highs in 2013, with $\mathrm{CO}_{2}$ at $396.0 \pm 0.1 \mathrm{ppm}, \mathrm{CH}_{4}$ at $1824 \pm 2 \mathrm{ppb}$ and $\mathrm{N} 2 \mathrm{O}$ at $325.9 \pm 0.1 \mathrm{ppb}$. These values constitute, respectively, $142 \%, 253 \%$ and $121 \%$ of pre-industrial (before 1750) levels. The atmospheric increase of $\mathrm{CO}_{2}$ from 2012 to 2013 was $2.9 \mathrm{ppm}$, which is the largest year to year change from 1984 to 2013. For $\mathrm{N}_{2} \mathrm{O}$ the increase from 2012 to 2013 is smaller than the one observed from 2011 to 2012 but comparable to the average growth rate over 
the past 10 years. Atmospheric $\mathrm{CH}_{4}$ continued to increase at a rate similar to the mean rate over the past five years. The National Oceanic and Atmospheric Administration (NOAA) Annual Greenhouse Gas Index shows that from 1990 to 2013 radiative forcing by long-lived greenhouse gases increased by $34 \%$, with $\mathrm{CO}_{2}$ accounting for about $80 \%$ of this increase (WMO, 2014).

The globally averaged combined land and ocean surface temperature data as calculated by a linear trend, show a warming of 0.85 [0.65 to 1.06$]^{\circ} \mathrm{C}$, over the period 1880 to 2012, when multiple independently produced datasets exist. The total increase between the average of the 1850-1900 period and the 2003-2012 period is 0.78 [0.72 to 0.85$]^{\circ} \mathrm{C}$, based on the single longest dataset available (IPCC, 2013). Scientific evidence shows that, since the industrial revolution, the burning of fossil fuels and the destruction of forests have caused the concentrations of heat-trapping greenhouse gases to increase significantly in our atmosphere, at a speed and magnitude much greater than natural fluctuations would dictate. If concentrations of greenhouse gases in the atmosphere continue to increase, the average temperature at the Earth's surface could grow from 1.8 to $4^{\circ} \mathrm{C}$ ( 3 to $7^{\circ} \mathrm{F}$ ) above 2000 levels by the end of this century (IPCC,2007c). Impacts of climate change, many of which are already being seen, include temperature increase, sea level rise, melting of glaciers and sea ice, increased coral bleaching, changes in the location of suitable habitat for plants and animals, more intense droughts, hurricanes and other extreme weather events, increased wildfire risk, and increased damage from floods and storms. The rural poor are often most at risk for being severely and negatively impacted by climate change, as their livelihoods are closely tied to ecosystems which provide water for drinking, wildlife for hunting and fishing, and medicinal plants. Deforestation and degradation also have detrimental effects on soils, reducing the amount of carbon stored in soils over time, as well as increasing erosion and polluting rivers.

Forests are estimated to store about 289 gigatonnes of carbon in their biomass alone; they therefore play a central role in the earth's carbon balance and hold significant potential to mitigate climate change (FAO, 2010b). Forests provide support for one billion people that live in extreme poverty around the world, and provide remunerative employment to more than one hundred million. They contain more than $80 \%$ of terrestrial biodiversity (FAO, 2012) and provide essential environmental services such as soil conservation, watershed management, protection against floods and landslides, and provide industrial wood (Violini, 2013).

Satellite remote sensing (SRS) which acquires information about the Earth's surface, subsurface and atmosphere remotely from sensors on board satellites is an important component of observation of impact of climate change on forests (Yang et al, 2013). The use of satellites allows the observation of states and processes of the atmosphere, land and ocean at several spatiotemporal scales. It is one of the most efficient approaches for monitoring land cover and its changes through time over a variety of spatial scales (Bontemps, S. et al. 2011; Gong, P. et al, 2013).

\section{MATERIALS AND METHODS}

Various research paper from the National and International Journals were extensively studied. The present paper discusses the role of remote sensing to improve our understanding on impact of climate change on the forests. Our main task is to reveal the unique contributions of remote sensing and geographic information system towards the impact of climate change on forest ecosystems. 
Various impacts of climate change on forest ecosystems have been studied with the help of remote sensing and Geographic Information System are reviewed.

FOREST FIRE: Fire is the most spectacular natural disturbance that affects the forest ecosystem composition and diversity. Fire has a devastating effect on the landscape and its impact is felt at every level of the ecosystem and it is possible to map forest fire risk zone and thereby minimize the frequency of fire. Fires can be monitored and analyzed over large areas in a timely and cost effective manner by using satellite imagery. Forest fires have been taking place historically, shaping landscape structure, pattern and ultimately the species composition of ecosystems. Remote sensing (RS) and Geographic Information Systems (GIS), provides the information and the tools necessary to develop a forest fire susceptibility map in order to identify, classify and map fire hazard area (Sowmya and Somashekhar, 2010)

TREELINE SHIFT: Alpine life zones are areas lying between the altitudinal treeline, or its substitutes, and the altitudinal limits of life, or the snow line. The alpine life zone is globally distributed, from polar to tropical latitudes, and occurs across oceanic and continental climates. Owing to the compression of thermal zones and isolation caused by low temperature, the alpine ecosystem usually shows high level of endemism and sensitivity to temperature change. The treeline species are at the threshold of their climatic limits. Factors related to tree growth or seed production and germination, such as temperature, precipitation, solar radiation, and wind or soil nutrient can inhibit the treeline from moving further towards higher latitudes or altitudes (Grace et al., 2002). Any change in the climate, which perturbs the vegetation-climate equilibrium, will lead to significant changes in the demographic patterns of these species. Amongst these, temperature is the most common limiting factor affecting various aspects of vegetation dynamics (Korner et al., 2004). Remote sensing is now recognized as an essential tool for viewing, analyzing and characterizing the alpine treeline ecotone (Butler et al., 2009). A study conducted on the monitoring of the alpine treeline shift in parts of the Indian Himalayas using remote sensing (Singh et al., 2012). The study revealed that the current vegetation lines cover about $5274 \mathrm{~km}$ surface distance. The average elevation of this line is $4158 \mathrm{~m}$ with maximum elevation of $6157 \mathrm{~m}$. During 1972, the other vegetation lines covered about $2010 \mathrm{~km}$ surface distance with an average elevation of $3447 \mathrm{~m}$. Thus, there is about $700 \mathrm{~m}$ upward shift in case of other alpine vegetation lines. Alpine meadows are converting into shrub lands in the southern Himalayas. To measure rates of meadow loss due to shrub encroachment and identify its mechanisms; alpine land cover, climate, and land use change from 1950 to 2009 across Northwest Yunnan using satellite data, ground surveys, and interviews were used. The study shows that between 1990 and 2009, at least 39\% of the alpine meadows converted to woody shrubs. The patterns of change suggest that a regime shift is occurring. This regime shift threatens both endemic meadow biodiversity and local livelihoods (Jodi et al., 2013).

CARBON STOCK ASSESSMENT: Major role played by remote sensing and geographic information system in forest management is the analysis of forest biomass and carbon stock which have significant role in climate change process. Detection of changes in biomass and carbon stocks of forest are key to natural resource management and monitoring. Bijalwan et al., (2010) have estimated the biomass and carbon in dry tropical forest of Chhatisgarh region in India using remote sensing and data and Geographic Information System (GIS). The highest volumes, above ground biomass and carbon storage per hectare were found in the mixed forest and lowest in degraded 
forest. Madugundu et al., (2008) estimated the above ground biomass in deciduous forests in Western Ghats of Karnataka using IRS P6 LISS-IV satellite data. Devagiri et al., (2013) have conducted an assessment of above ground biomass and carbon pool indifferent vegetation types of Karnataka using spectral modeling. The study integrates field measured biomass with spectral responses of different bands and indices of MODIS $250 \mathrm{~m}$ spatial resolution. Field measured above ground biomass (AGB) ranged between 7.25 to $287.05 \mathrm{t} \mathrm{ha}^{-1}$ across different vegetation types in the region. Regression analysis was carried out between biomass obtained through spectral modeling (predicted biomass) and estimates of area weighted biomass based on field measurements High $\mathrm{R}^{2}(0.807)$ value indicates a significant positive relationship between predicted and area weighted biomass estimates suggesting that the remote sensing technique could be used confidently for quick and reliable estimates of biomass and carbon. Forest Survey of India (FSI) estimated the carbon stock of Indian forests between 1994-2004 by using remotely sensed data of sample areas and field survey method. A comparison of carbon stock between 1994 and 2004 was conducted which showed that there is net increase of 592 Mt carbon stock in India's Forests (ISFR, 2011). Monitoring of carbon stock will be helpful in designing policies with regards to International Climate Change mitigation programmes like REDD-plus. Remote Sensing based methodologies can be developed for Measuring, Reporting and Verification (MRV) of climate change mitigation programme for the generation and issuance of carbon credits which are under negotiation in United Nations Framework Convention on Climate Change (UNFCCC).

BIODIVERSITY CHARACTERIZATION: India, the second most populous country in the world, is the $11^{\text {th }}$ mega-biodiversity center of the world and the third in Asia, with a share of about $11 \%$ of the total plant resources. The floral wealth of India comprises more than 47, 000 species including 43\% vascular plants. Nearly 147 Genera are endemic to India (Nayar, 1996; Roy et al., 2012). Climate Change and increasing anthropogenic pressure on the biodiversity are major cause of biodiversity extinction. Baseline data is required to study the impact of climate change on biodiversity. Roy et al., (2012) has done an assessment of biodiversity characterization at landscape level. 150 vegetation and land use classes are delineated using visual interpretation technique at 1:50,000 scale. The baseline data is significant for prioritizing the biodiversity conservation and developing management strategies for protecting the species under the effect of climate change.

SPECIES DISTRIBUTION: It is important to study the species distribution due to the impact of climate change. Various studies have been conducted to analyze the potential impact of climate change on species distribution (Mac Nally and Fleishman 2004, Burgman et al. 2005, Singh et al., 2012). Analysis was carried out to evaluate the fundamental environmental niche of Betula utilis under climatic conditions. Betula utilis bioclimatic envelop overlaps $84 \%$ of the remotely sensed treeline ecotone. This establishes the fact that the environmental conditions of the alpine zone of Uttarakhand are conducive for the dominance of B. utilis as a treeline species (Singh et al., 2013). Kushwaha et al. (2005) have conducted the study on plant richness modeling at ecosystem level (on 1:50,000 scale) in Barsey Rhododendron Sanctuary in Sikkim Himalayan state of India.

Study is helpful in plant richness assessment over large, relatively homogeneous areas, and can be useful in regional level biodiversity conservation prioritization and management. Often, knowledge about the locations of populations of species is constrained by limited field surveys owing to rugged terrain and low population sizes with widely dispersed individuals. Precise information on species' distributions and ecology is important for assessing conservation status of 
endangered and rare species, and developing effective in situ and ex situ conservation and reintroduction strategies. All of these benefits can be leveraged still further using novel, GIS-based ecological niche modeling techniques that can assist in locating new populations as well as identifying suitable areas for reintroduction (Soberón and Peterson, 2005; Siqueira et al., 2009). Ecological niche modeling (ENM), which combines known species' occurrence records with relevant environmental data layers to estimate species' ecological requirements and potential geographic distributions of Rhododendron species in the Indian Eastern Himalayas

HABITAT ASSESSMENT: Remote sensing provides several useful input variables such as vegetation type and density, biome, landscape or eco-region maps (Turner et al., 2003; Kushwaha, 2011) while the Geographic Information System (GIS) happens to be an ideal tool for geospatial database creation, data integration and modeling (Irfan-Ullah et al., 2006). Models predicting the potential geographic distribution of species are important for a variety of applications in conservation biology (Ferrier, 2002; Graham et al., 2004). A large number of statistical models are currently in use to simulate the spatial distribution of plant species (Kumar and Stohlgren, 2009; Adhikari et al., 2012), spread of invasive species (Peterson et al., 2003; Thuiller et al., 2005), spatial patterns of species diversity (Graham et al., 2006), or impact of climate change (Thomas et al., 2004; Saran et al., 2010). Maximum entropy (Maxent) model (Phillips et al., 2004) is a species distribution model (SDM) originating from the statistical mechanics (Jaynes, 1957). It is a general purpose environmental model for predicting the potential distribution of species. The method has several advantages; it requires only species presence (or occurrence) data and environmental information (Elith et al., 2011).

Xue-Qing Yang et al. (2013) showed that the model output provided satisfactory results with the given set of training and test data, the final model had high accuracy with an AUC value of 92.3. It is important to note that AUC values tend to be lower for species that have broad distribution scope (Mcpherson and Jetz, 2007; Evangelista et al., 2008). The eastern part of Dun valley, in general, has higher potential than the western part for Justicia adhatoda, which could primarily be attributed to the LULC types in this part of the Valley, i.e. open forest, scrub, agricultural land, forest plantations, and the non-forest areas. The model results showed that an area of $638.80 \mathrm{~km}^{2}$ $(34.03 \%)$ has high to good potential. Approximately $574.38 \mathrm{~km}^{2}(30.6 \%)$ area showed medium potential while $663.82 \mathrm{~km}^{2}(35.37 \%)$ area showed least potential. The least potential area is mostly covered by dense forest, which is an unsuitable habitat for light loving $J$. adhatoda.

\section{CONCLUSION}

In this paper, we analyzed that Remote Sensing and GIS has a pivotal role in climate change studies related to forest ecosystem. Landscape based studies conducted through remote sensing and GIS can be a valuable tool in species conservation planning and species distribution. It helps us to understand the ecosystem as a whole by combining various factors like anthropogenic pressure, bioclimatic variable and biophysical parameters. Earth observation alongwith the ground truthing provides useful information which can lead to the development of various tools and models to have better understanding of climate change impact on forest ecosystem. Baseline regarding the carbon stock, biodiversity and the impact of local people on the forest ecosystem can be generated using the time series data from various available satellites. 


\section{ACKNOWLEDGEMENT}

Authors are thankful to Dr. Subrata Nandy, Scientist-SD, Indian Institute of Remote Sensing, Dehradun for his valuable suggestions and encouragement.

\section{REFERENCES}

[1] Adhikari, D., Barik, S.K. and Upadhaya, K. (2012). Habitat distribution modelling for reintroduction of Ilex khasiana Purk., a critically endangered tree species of northeastern India. Ecol. Eng. 40, 37-43.

[2] Bijalwan, A., Swamy, S. L., Sharma, C.M., Sharma, N.K. and Tiwari A. K. (2010). Land-use, biomass and carbon estimation in dry tropical forest of Chhattisgarh region in India using satellite remote sensing and GIS. Journal of Forestry Research, June 2010, Volume 21, Issue 2, pp 161170.

[3] Bontemps, S., Herold, M., Kooistra, L., Groenestijn, A., Hartley, A., Arino, O., Moreau, I. and Defourny, P. (2011). Revisiting land cover observations to address the needs of the climate modelling community. Biogeosci. Discuss. 8, 7713-7740.

[4] Burgman, M., Lindenmayer, D. B. and Elith, J. (2005). Managing landscapes for conservation under uncertainty. Ecology 86: 2007-2017.

[5] Butler, David R., George P. Malanson, Lynn M. Resler, Stephen J. Walsh, Forrest D. Wilkerson, Ginger L. Schmid and Carol F. Sawyer. (2009). Geomorphic patterns and processes at alpine treeline. Chapter 4. In, The Changing Alpine Treeline of Glacier National Park, Montana, USA. Eds. David R. Butler, George P. Malanson, J. Walsh and Daniel B. Fagre. Developments in Earth Surface Processes, Volume 12. Elsevier Press: Dordrecht The Netherlands. Pgs. 63-84.

[6] Devagiri, G. M., Money, S., Singh,S., Dadhawal, V. K., Patil, P., Khaple, A.K., Devakumar, A. S. and Hubballi, S. (2013). Assessment of above ground biomass and carbon pool in different vegetation types of south western part of Karnataka, India using spectral modeling. Tropical Ecology 54(2): 149-165.

[7] Elith, J., Phillips, S.J., Hastie, T., Dudik, M., Chee, Y.E. and Yates, C.J. (2011). A statistical explanation of Maxent for ecologists. Divers. Distrib. 17, 43-57.

[8] Evangelista, P.H., Kumar, S., Stohlgren, T.J., Jarnevich, C.S., Crall, A.W., Norman, J.B. and Barnett, D.T., (2008). Modelling invasion for a habitat generalist and a specialist-plant species. Divers. Distrib. 14, 808-817.

[9] FAO. (2010b). Global Forest Resources Assessment 2010 - main report. FAO Forestry Paper No. 163. Rome.

[10] FAO. (2012). State of the World's Forests 2012. Rome.

[11] Ferrier, S., (2002). Mapping spatial pattern in biodiversity for regional conservation planning: where to from here? Syst. Biol. 51, 331-363.

[12] Gong, P. et al. (2013). Finer resolution observation and monitoring of global land cover: first mapping results with Landsat TM and ETM+ data. Int. J. Remote Sens. 34, 2607-2654 (2013). [13] Grace, J., Berninger, F. and Nagy, L. (2002). Impacts of Climate Change on the Tree Line Ann. Bot., 90, 537-544. 
[14] Graham, C.H., Ferrier, S., Huettman, F., Moritz, C. and Peterson, A.T. (2004). New developments in museum-based informatics and applications in biodiversity analysis. Trends Ecol. Evol. 19, 497-503.

[15] Graham, C.H., Moritz, C. and Williams, S.E., (2006). Habitat history improves prediction of biodiversity in a rainforest fauna. Proc. Natl. Acad. Sci. U.S.A. 103, 632-636.

[16] IPCC. (2007). Summary for Policymakers. In: Climate Change 2007: The Physical Science Basis. Contribution of Working Group I to the Fourth Assessment Report of the Intergovernmental Panel on Climate Change [Solomon, S., D. Qin, M. Manning, Z. Chen, M. Marquis, K.B. Averyt, M.Tignor and H.L. Miller (eds.)]. Cambridge University Press, Cambridge, United Kingdom and New York, NY, USA.

[17] IPCC. (2013): Summary for Policymakers. In: Climate Change 2013: The Physical Science Basis. Contribution of Working Group I to the Fifth Assessment Report of the Intergovernmental Panel on Climate Change [Stocker, T.F., D. Qin, G.-K. Plattner, M. Tignor, S.K. Allen, J. Boschung, A. Nauels, Y. Xia, V. Bex and P.M. Midgley (eds.)]. Cambridge University Press, Cambridge, United Kingdom and New York, NY, USA.

[18] Irfan-Ullah, M., Amarnath, G., Murthy, M.S.R. and Peterson, A.T. (2006). Mapping the geographic distribution of Aglaia bourdillonii Gamble (Meliaceae), an endemic and threatened plant using ecological niche modeling. Biodivers. Conserv. 16, 1917-1925.

[19] ISFR. (2011). India State of Forest Report 2011. Forest Survey of India, Ministry of Environment and Forests, Gov. of India, Dehradun.

[20] Jaynes, E.T. (1957). Information theory and statistical mechanics. Phys. Rev. 106, 620-630. [21] Jodi, S. B., Haynes, M.A., Kuemmerle, T., Waller, D.M. and Radeloff, V.C., (2013). Regime shift on the roof of the world: Alpine meadows converting to Shrublands in the southern Himalayas. Biological Conservation 158 (2013) 116-127

[22] Körner, C. and Paulsen, J. (2004). A world-wide study of high altitude treeline temperatures. J. Biogeogr 31, 713-732.

[23] Kumar, S. and Stohlgren, T.J. (2009). Maxent modeling for predicting suitable habitat for threatened and endangered tree Canacomyrica monticola in New Caledonia. J. Ecol. Nat. Environ. 1, 94-98.

[24] Kushwaha, S.P.S., Padmanaban, P., Kumar, D., and Roy, P.S. (2005). Geospatial Modeling of Plant Richness in Barsey Rhododendron Sanctuary in Sikkim Himalayas Geocarto International, Vol. 20, No. 2, June 2005.

[25] Kushwaha, S.P.S., (2011) .Remote sensing of invasive alien plant species. In: Bhatt, J.R., Singh, J.S., Tripathi, R.S., Singh, S.P., Kohli, R.K. (Eds.), Invasive Alien Plants - An Ecological Appraisal For the Indian Sub-continent. CABI, Oxfordshire, pp. 131-138.

[26] Mac Nally, R. and Fleishman, E. (2004). A successful predictive model of species richness based on indicator species. Conservation Biology 18: 646-654.

[27] Madugundu, R., Vyjayanthi, N. and Jha, C. S. (2008). Estimation of LAI and above-ground biomass in deciduous forests: Western Ghats of Karnataka, India. International Journal of Applied Earth Observation and Geoinformation 10: 211-219.

[28] Mcpherson, J.M. and Jetz, W. (2007). Effects of species' ecology on the accuracy of distribution models. Ecography 30, 135-151.

[29] Nayar, M.P. (1996). Hot Spots of Endemic Plants of India, Nepal and Bhutan. Tropical Botanical Garden and Research Institute, Thiruvananthapuram.

[30] Peterson, A.T., Papes, M. and Kluza, D.A. (2003). Predicting the potential invasive distributions of four alien plant species in North America. Weed Sci. 51, 863-868. 
[31] Phillips, S.J., Miroslav, D. and Schapire, R.E., (2004). Maxent Software for Species Distribution Modeling. http://cs.princeton.edu/ schapire/Maxent/

[32] Roy, P.S., Kushwaha, S.P.S., Murhty, M.S.R., Roy, A., Kushwaha, D., Reddy, C.S., Behera, M.D., Mathur, V.B., Padalia, H., Saran, S., Singh, S., Jha, C.S. and Porwal, M.C. (2012). Biodiversity Characterisation at Landscape Level: National Assessment, Indian Institute of Remote Sensing, Dehradun, India, pp. 140. ISBN 81-901418-8-0.

[33] Saran, S., Joshi, R., Sharma, S., Padalia, H. and Dadhwal, V.K., (2010). Geospatial modelling of brown oak (Quercus semecarpifolia Sm.) habitats in the Kumaun Himalaya under climate change scenario. J. Indian Soc. Remote Sens. 38, 534-547.

[34] Singh, C. P., Panigrahy, S., Thapliyal, A., Kimothi, M. M., Soni, P. and Parihar, J. S. (2012). Monitoring the alpine treeline shift in parts of the Indian Himalayas using remote sensing. Current Science, vol. 102, no. 4,559-562.

[35] Singh, C. P., Panigrahy, S., Parihar, J.S. and Dharaiya, N. (2013). Modeling environmental niche of Himalayan birch and remote sensing based vicarious validation. Tropical Ecology 54(3): 321-329.

[36] Siqueira, M.F., Durigan, G., Junior, P.M. and Peterson, A.T. (2009). Something from nothing: Using landscape similarity and ecological niche modeling to find rare plant species. Journal for Nature Conservation 17(1): 25-32.

[37] Soberón, J. and Peterson, A.T. (2005). Interpretation of models of fundamental ecological niches and species' distributional areas. Biodiversity Informatics 2: 1-10.

[38] Sowmya, S.V. and Somashekar, R.K. (2010). Application of remote sensing and geographical information system in mapping forest fire risk zone at Bhadra wildlife sanctuary, India Journal of Environmental Biology, 31(6) 969-974.

[39] Thomas, C.D., Cameron, A., Green, R.E., Bakkenes, M., Beaumont, L.J., Collingham, Y.C., Erasmus, B.F.N., de Siqueira, M.F., Grainger, A., Hannah, L., Hughes, L., Huntley, B., van Aarsveld, A.S., Midgley, G.F., Miles, L., Ortega-Huerta, M.A., Peterson, A.T., Phillips, O.L. and Williams, S.E., (2004). Extinction risk from climate change. Nature 27, 145-147.

[40] Thuiller, W., Richardson, D.M., Py̌sek, P., Midgley, G.F., Hughs, G.O. and Rouget, M., (2005). Niche-based modeling as a tool for predicting the risk of alien plant invasions at a global scale. Global Change Biol. 11, 2234-2250.

[41] Turner, W., Spector, S., Gardiner, N., Fladeland, M., Sterling, E. and Steininger, M. (2003). Remote sensing for biodiversity science and conservation. Trends Ecol. Evol. 18, 306-314.

[42] Violini, S. (2013). Deforestation: Change Detection in Forest Cover using Remote Sensing. Seminary - Master in Emergency Early Warning and Response Space Applications. Mario Gulich Institute, CONAE. Argentina. 1-28.

[43] WMO. (2014). Greenhouse Gas Bulletin, No. $10 \mid 9$ September 2014.

[44] Xue-Qing Yang, Kushwaha, S.P.S., Saran, S., Jianchu X, and P.S. Roy. (2013). Maxent modeling for predicting the potential distribution of medicinal plant, Justicia adhatoda L. in Lesser Himalayan foothills. Ecological Engineering 51, 83- 87.

[45] Yang, Y., Gong, P., Fu, R., Zhang, M., Chen, J., Liang, S., Xu, B., Shi, J. and Dickinson. R. (2013). The role of satellite remote sensing in climate change studies. Nature Climate Change 3, 875883. 